\title{
Graphitic Carbon Nitride Microtubes for Efficient Photocatalytic Overall Water Splitting: The Morphology Derived Electrical Field Enhancement
}

Lin Chen ${ }^{\mathrm{a}}$, Xiaoli Zhao ${ }^{\mathrm{b}}$, Xiaoguang Duan ${ }^{\mathrm{e}}$, Jinqiang Zhang ${ }^{\mathrm{b}}$, Zhimin $\mathrm{Ao}^{\mathrm{d}}$, Pan $\mathrm{Li}^{\mathrm{c}}$, Shuaijun Wang,b,*, Yixuan Wang ${ }^{\mathrm{a}}$, Shuai Chenga ${ }^{\mathrm{a}}$, Hongfei Zhao ${ }^{\mathrm{a}}$, Fengting Hea ${ }^{\mathrm{a}}$, Pei

Dong $^{\mathrm{a}}$, Chaocheng Zhao ${ }^{\mathrm{a}, *}$, Shaobin Wang ${ }^{\mathrm{e}}$, and Hongqi Sun ${ }^{\mathrm{b}, *}$

a State Key Laboratory of Petroleum Pollution Control, China University of Petroleum (East China), 66 West Changjiang Road, Qingdao 266580, PR China

${ }^{b}$ School of Engineering, Edith Cowan University, 270 Joondalup Drive, Joondalup, WA 6027, Australia

c Henan Engineering Center of New Energy Battery Materials, Henan D\&A Engineering Center of Advanced Battery Materials, College of Chemistry and Chemical Engineering, Shangqiu Normal University, 298 Wenhua Middle Road, Shangqiu 476000, PR China

${ }^{d}$ Guangdong Key Laboratory of Environmental Catalysis and Health Risk Control, Institute of Environmental Health and Pollution Control, School of Environmental Science and Engineering, Guangdong University of Technology, 729 Dongfeng East Road, Guangzhou 51006, PR China

e School of Chemical Engineering, The University of Adelaide, 108 King William Street, Adelaide, SA 5005, Australia

*Corresponding Author

E-mail: h.sun@ecu.edu.au (H. Sun); zhaochch@upc.edu.cn (C. Zhao);

shuaijunwang@outlook.com (S. Wang).

Number of Pages: 22

Number of Figures: 18

Number of Tables: 5 


\section{Supporting text}

\section{S1. Experimental Section}

\section{S1.1. Materials}

All reagents were provided by Sinopharm Chemical Reagent Co., if not specified. These chemicals were directly used without further purification.

\section{S1.2. Synthesis of pure $\mathrm{g}-\mathrm{C}_{3} \mathrm{~N}_{4}$ :}

Typically, $5 \mathrm{~g}$ of melamine was placed into a porcelain crucible and calcined at $500{ }^{\circ} \mathrm{C}$ for $4 \mathrm{~h}$ in $\mathrm{N}_{2}$ atmosphere at a heating rate of $2.3{ }^{\circ} \mathrm{C} \mathrm{min}^{-1}$. The product was then ground to fine powder.

\section{S1.3. Synthesis of graphitic carbon nitride microtubes (TCN):}

Firstly, $1.0 \mathrm{~g}$ melamine $(8 \mathrm{mmol})$ and phosphoric acid $\left(\mathrm{H}_{3} \mathrm{PO}_{4}\right)$ with different amounts $(0.5,1.0$ and $2.0 \mathrm{~g})$ were dissolved in $70 \mathrm{~mL}$ deionized water with strong stirring for $30 \mathrm{~min}$. The mixture was then transferred into a $100 \mathrm{~mL}$ autoclave with Teflon liner and reacted at $180{ }^{\circ} \mathrm{C}$ for $10 \mathrm{~h}$. After cooling to room temperature, the obtained supramolecular precursor was washed with deionized water, and then dried at $60{ }^{\circ} \mathrm{C}$. Finally, the obtained precursor was polymerized at $500{ }^{\circ} \mathrm{C}$ for $4 \mathrm{~h}$ under $\mathrm{N}_{2}$ atmosphere at a heating rate of $2.3{ }^{\circ} \mathrm{C} \mathrm{min}-1$. The resulting materials were designated as $\mathrm{TCN}-\mathrm{X}(\mathrm{X}=0.5,1.0,2.0)$.

\section{S1.4. Synthesis of phosphorus-doped carbon nitride microrods (PCN):}

Firstly, $1.0 \mathrm{~g}$ melamine $(8 \mathrm{mmol})$ and $1 \mathrm{~g}$ phosphoric acid were dissolved in $70 \mathrm{~mL}$ deionized water with vigorous stirring for $30 \mathrm{~min}$. The mixture was then transferred into a $100 \mathrm{~mL}$ autoclave with Teflon liner and reacted at $180{ }^{\circ} \mathrm{C}$ for $10 \mathrm{~h}$. After 
cooling to room temperature, the obtained supramolecular precursor was directly dried at $60{ }^{\circ} \mathrm{C}$. Finally, the obtained precursor was heated to $500{ }^{\circ} \mathrm{C}$ for $4 \mathrm{~h}$ under $\mathrm{N}_{2}$ atmosphere at a heating rate of $2.3{ }^{\circ} \mathrm{C} \mathrm{min}^{-1}$. The yield product was $\mathrm{PCN}$.

\section{S2. Characterization}

The transmission electron microscopy (TEM) and scanning electron microscopy (SEM) were respectively taken on the JEOL 2100 TEM instrument and FEI S4800 instrument. X-ray powder diffraction (XRD) patterns were obtained on a Holland X'Pert Pro diffractometer. X-ray photoelectron spectroscopy (XPS) was performed using an ESCALAB 250xi spectrometer. Fourier transform infrared spectra (FT-IR) were recorded on a Nicolet Nexus 670 spectrometer $\left(400-4000 \mathrm{~cm}^{-1}\right)$. The UV-vis diffuse reflectance spectra (DRS) were collected on a TU-1901 spectrometer with $\mathrm{BaSO}_{4}$ as a reflectance standard. The photoluminescence (PL) spectra were recorded in a Hitachi F-4600 luminescence spectrophotometer. The specific surface area was determined based on the Brunauer-Emmett-Teller (BET) method by using the $\mathrm{N}_{2}$ adsorption-desorption apparatus (Micromeritics, ASAP 2010). Electron paramagnetic resonance (EPR) spectroscopy was applied for the catalysts (Bruker A200). The electrochemical impedance spectra (EIS) and transient photocurrents were measured on electrochemical workstation (CHI-660 B, China) with a three-electrode system by using $0.1 \mathrm{M} \mathrm{Na}_{2} \mathrm{SO}_{4}$ aqueous solution as the electrolyte, where the sample/FTO with an active area of $1 \mathrm{~cm}^{2}$ was used as the working electrode, a Pt line was the counter electrode, and $\mathrm{Ag} / \mathrm{AgCl}$ (saturated $\mathrm{KCl}$ ) was the reference electrode. NMR was carried out on a Bruker ADVANCEII $500 \mathrm{MHz}$ equipment. 


\section{S3. Density Function Theory (DFT) Calculations and Finite Element Modelling}

(FEM)

In this work, we used the CASTEP code ${ }^{1}$ for DFT calculations. A plane-wave basis set was adopted, together with the generalized gradient approximation (GGA) and Perdew-Burke-Ernzerhof (PBE) functional ${ }^{2}$. The Brillouin zone was sampled with 3 $\times 3 \times 4 k$-point, and the cut off energy was set to $340 \mathrm{eV}$. In all the models, the separation between adjacent layers was set to $15 \AA$ to minimize the interlay interaction. For the plain $\mathrm{g}-\mathrm{C}_{3} \mathrm{~N}_{4}$ structure we adapted the well-accepted model of a polymeric melon sheet ${ }^{3-4}$, with the lattice parameters of the polymeric melon are 16.7 $\times 12.4 \AA$, see Figure S9a. Further modelling details were presented in our previous works ${ }^{5-6}$.

Finite element modelling (FEM) was carried out in this work to simulate the behaviours of the electrical field resulted from the interactions between the incoming radiation field, the $\mathrm{g}-\mathrm{C}_{3} \mathrm{~N}_{4}$ tube, and the surrounding reactant, using COMSOL software ${ }^{7}$. The electromagnetic field distribution, induced by the incoming light irradiation and scattered by the photocatalyst $\left(\mathrm{g}-\mathrm{C}_{3} \mathrm{~N}_{4}\right.$ rod or tube) within the reactant (by using the physical parameters of water as an approximation), was evaluated by solving classical Maxwell equations. To validate the full 3D model, an Au sphere of $30 \mathrm{~nm}$ radius was constructed within a rectangle domain. Perfect matching layers (PMLs) were defined at both the top and at the bottom of the model, to completely absorb all the reflected and/or transmitted waves with arbitrary wave front, so as to remove any interference of back-reflected waves. From the solution of the model, the resultant heat generation was obtained, which was in excellent agreement with that 
obtained from the analytical solution ${ }^{8}$, validating both the correctness and the accuracy of our model. Based on the full 3D prototype, a 2D FEM model consists of a rectangle domain filled with reactant (water) with a $\mathrm{g}-\mathrm{C}_{3} \mathrm{~N}_{4}$ sphere (or a ring) representing the cross section of a catalyst rod (or a sphere). The optical parameters of plain $\mathrm{g}-\mathrm{C}_{3} \mathrm{~N}_{4}$ were adopted from the previous literature ${ }^{9}$, while those for the $\mathrm{P}$ doped were obtained from the $\mathrm{g}-\mathrm{C}_{3} \mathrm{~N}_{4}$ DFT calculations. An incident electro-magnetic radiation within the visible range is set at the top, transmitting downwards vertically with an intensity of $10^{4} \mathrm{~W} / \mathrm{m}^{2}$. Schematic representations of the FEM models are shown in Figure S10.

\section{S4. Photocatalytic $\mathrm{H}_{2}$ evolution and overall water splitting}

The photocatalytic hydrogen production experiments were carried out in an online photocatalytic hydrogen production closed circulation system (CEL-SPH2N-D5) at $6{ }^{\circ} \mathrm{C}$ using a flow of cooling water. $25 \mathrm{mg}$ of the catalyst was dispersed into $25 \mathrm{~mL}$ aqueous solution containing $2.5 \mathrm{~mL}$ of triethanolamine (TEOA), and $3.0 \mathrm{wt} \% \mathrm{Pt}$. Before the reaction, the reactor was deaerated by evacuation to remove air dissolved in water. A Xenon $300 \mathrm{~W}$ lamp (CEL-HXF300, AuLight, China) with a $420 \mathrm{~nm}$ cut-off filter was used as a light irradiation source. Gas evolution was observed only under irradiation and analyzed by an on-line gas chromatograph (GC7920, Techcomp, TCD, $\mathrm{N}_{2}$ carrier, molecular sieve $5 \AA$ ).

The overall water splitting process was performed using the same equipment with some parameters changed. In detail, $50 \mathrm{mg}$ of the catalyst, $3.0 \mathrm{wt} \% \mathrm{H}_{2} \mathrm{PtCl}_{6} \cdot\left(\mathrm{H}_{2} \mathrm{O}\right)_{6}$, and $1.0 \mathrm{wt} \% \mathrm{RuCl}_{3}$ were dispersed into a $100 \mathrm{~mL}$ aqueous solution. It should be noted 
that any sacrificial regent was not added. Prior to irradiation $(\lambda>350 \mathrm{~nm})$, the suspension was sonicated for $30 \mathrm{~min}$ and evacuated thoroughly to remove any air. The photocatalytic evolved hydrogen and oxygen was then analyzed by an on-line gas chromatograph (GC7920, Techcomp, TCD detector, carrier gas: Argon, 5A molecular sieve column).

\section{S5. Apparent Quantum Efficiency (AQE) Calculation}

In terms of apparent quantum efficiency (AQE), the reaction was carried out in 100 $\mathrm{mL}$ solution (contained $50 \mathrm{mg}$ catalyst, $10 \mathrm{vol} \%$ TEOA, and $3.0 \mathrm{wt} \% \mathrm{H}_{2} \mathrm{PtCl}$ $\left.{ }_{6} \cdot\left(\mathrm{H}_{2} \mathrm{O}\right)_{6}\right)$. The Xe lamp was also replaced by the monochromatic LED light $(395,420$, 500 , and $595 \mathrm{~nm}, \lambda \pm 10 \mathrm{~nm})$. Other experimental parameters are the same as the photocatalytic $\mathrm{H}_{2}$ evolution process. The light intensity was monitored by an optical power meter (CEL-NP2000-2). The number of incident photons $(N)$ is calculated by Eq. $S 1$, and the AQE is then calculated in Eq. $S 2$, and the detailed parameters were provided in Table S5.

$$
\begin{gathered}
N=\frac{E \lambda}{h c}=\frac{I \times S \times t \times \lambda}{h c} \quad \text { Eq. } S 1 \\
A Q E=\frac{\text { the number of reacted electrons }}{\text { the number of incident photons }} \times 100 \% \\
=\frac{2 \times \text { the number of evolved } \mathrm{H}_{2} \text { molecules }}{N} \times 100 \% \\
=\frac{2 \times 6.02 \times 10^{23} \times \mathrm{n}\left(\mathrm{H}_{2}\right)}{N} \times 100 \% \quad \text { Eq. } S 2
\end{gathered}
$$

In which $I$ was the light intensity, $S$ was the irradiation area, $t$ was the $\mathrm{H}_{2}$ production time, $h$ was Planck's constant, and $c$ was the speed of light. Here we take TCN as an example. 
$\lambda=395 \mathrm{~nm}:$

Using Eq. S1: $N=1.60 \times 10^{20}$

Using Eq. S2: $A Q E=5.49 \times 100 \%$

$\lambda=420 \mathrm{~nm}:$

Using Eq. S1: $N=1.65 \times 10^{20}$

Using Eq. S2: $A Q E=3.27 \%$

$\lambda=500 \mathrm{~nm}:$

Using Eq. S1: $N=6.62 \times 10^{19}$

Using Eq. S2: $A Q E=0.41 \%$

$\lambda=595 \mathrm{~nm}:$

Using Eq. S1: $N=2.31 \times 10^{20}$

Using Eq. S2: $A Q E=0.01 \%$ 
Table S1. Textural properties of the prepared samples.

\begin{tabular}{cccc}
\hline Samples & $\mathrm{S}_{\mathrm{BET}}\left(\mathrm{m}^{2} \mathrm{~g}^{-1}\right)$ & Pore size $(\mathrm{nm})$ & Pore volume $\left(\mathrm{cm}^{3} \mathrm{~g}^{-1}\right)$ \\
\hline $\mathrm{g}-\mathrm{C}_{3} \mathrm{~N}_{4}$ & 5.2 & 27.3 & 0.026 \\
$\mathrm{PCN}$ & 14.8 & 15.5 & 0.044 \\
$\mathrm{TCN}$ & 26.7 & 16.5 & 0.095 \\
\hline
\end{tabular}

Table S2. Summary of the time-resolved transient PL decay spectra for the prepared samples.

\begin{tabular}{cccccc}
\hline Samples & $A_{1}$ & $\tau_{1}(\mathrm{~ns})$ & $A_{2}$ & $\tau_{2}(\mathrm{~ns})$ & $\tau(\mathrm{ns})$ \\
\hline $\mathrm{g}-\mathrm{C}_{3} \mathrm{~N}_{4}$ & 688.744 & 2.77 & 264.08 & 12.18 & 8.67 \\
$\mathrm{PCN}$ & 808.178 & 2.37 & 207.12 & 12.94 & 8.53 \\
$\mathrm{TCN}$ & 727.068 & 2.45 & 247.86 & 13.88 & 9.98 \\
\hline
\end{tabular}


Table S3. Summary of $g-\mathrm{C}_{3} \mathrm{~N}_{4}$-based nanostructures photocatalysts reported for overall water splitting.

\begin{tabular}{|c|c|c|c|c|c|c|}
\hline $\begin{array}{l}\text { Photocat } \\
\text { alysts }\end{array}$ & $\begin{array}{l}\text { Catalysts } \\
\text { mass(mg) }\end{array}$ & Co-catalyst & Light Source & $\begin{array}{c}\mathrm{H}_{2} \text { evolution } \\
\text { rate } \\
\left(\mu \mathrm{mol} \mathrm{g}{ }^{-1} \mathrm{~h}^{-1}\right)\end{array}$ & $\begin{array}{c}\mathrm{O}_{2} \text { evolution } \\
\text { rate } \\
\left(\mu \mathrm{mol} \mathrm{g} \mathrm{g}^{-1} \mathrm{~h}^{-1}\right)\end{array}$ & Ref. \\
\hline TCN & 50 & $\begin{array}{l}3 w t . \% \mathrm{Pt} \\
1 \mathrm{wt} \% \mathrm{Ru}\end{array}$ & $\begin{array}{c}300 \mathrm{~W} \text { Xe lamp } \\
\lambda>350 \mathrm{~nm}\end{array}$ & 110.3 & 44.7 & $\begin{array}{l}\text { This } \\
\text { work }\end{array}$ \\
\hline $\begin{array}{c}3 \mathrm{D} \\
\mathrm{g}-\mathrm{C}_{3} \mathrm{~N}_{4} \\
\mathrm{NS}\end{array}$ & 50 & $\begin{array}{l}1.0 \mathrm{wt} \% \mathrm{Pt} \\
3.0 \mathrm{wt} \% \mathrm{IrO}_{2}\end{array}$ & $\begin{array}{l}\text { 300W Xe lamp, } \\
\quad \lambda>300 \mathrm{~nm}\end{array}$ & 101.4 & 49.1 & 10 \\
\hline $\mathrm{Pt} / \mathrm{g}-\mathrm{C}_{3} \mathrm{~N}_{4}$ & 200 & $\begin{array}{c}3.0 \mathrm{wt} \% \mathrm{Pt} \\
1.0 \mathrm{wt} \% \mathrm{CoO}_{\mathrm{x}}\end{array}$ & $\begin{array}{c}\text { 300W Xe lamp, } \\
\lambda>420 \mathrm{~nm}\end{array}$ & 6 & 3 & 11 \\
\hline $\begin{array}{c}\mathrm{Co}_{3} \mathrm{O}_{4} / \mathrm{H} \\
\mathrm{CNS} / \mathrm{Pt}\end{array}$ & 20 & $\begin{array}{l}\mathrm{Pt} \text { and } \\
\mathrm{Co}_{3} \mathrm{O}_{4}\end{array}$ & $\begin{array}{c}300 \mathrm{~W} \text { Xe lamp } \\
\lambda \geq 300 \mathrm{~nm}\end{array}$ & 15.5 & 7.5 & 12 \\
\hline $\begin{array}{l}\mathrm{a}-\mathrm{Fe}_{2} \mathrm{O}_{3} / 2 \\
\text { D-g- } \mathrm{C}_{3} \mathrm{~N}_{4}\end{array}$ & 10 & $\begin{array}{c}3.0 \mathrm{wt} \% \mathrm{Pt}, 0.1 \\
\mathrm{wt} \% \mathrm{RuO}_{2}\end{array}$ & $\begin{array}{c}\text { 300W Xe lamp } \\
\lambda>300 \mathrm{~nm}\end{array}$ & 38.2 & 19.1 & 13 \\
\hline $\begin{array}{c}\mathrm{BP} / \mathrm{BiVO} \\
4\end{array}$ & 5 & None & $\begin{array}{l}\text { 320W Xe lamp } \\
\quad \lambda>420 \mathrm{~nm}\end{array}$ & 160 & 102 & 14 \\
\hline $\begin{array}{c}\mathrm{g}-\mathrm{C}_{3} \mathrm{~N}_{4}+ \\
\mathrm{WO}_{3}\end{array}$ & N/A & $\begin{array}{c}3.0 \mathrm{wt} \% \mathrm{Pt} / \\
\mathrm{g}-\mathrm{C}_{3} \mathrm{~N}_{4}, 0.5 \mathrm{wt} \% \\
\mathrm{Pt} / \mathrm{WO}_{3}, 5 \\
\mathrm{mMNaI}\end{array}$ & $\begin{array}{l}\text { 300W Xe lamp, } \\
\quad \lambda>395 \mathrm{~nm}\end{array}$ & 74 & 37 & 15 \\
\hline $\begin{array}{c}\text { CDots- } \mathrm{C}_{3} \\
\mathrm{~N}_{4}\end{array}$ & 80 & None & $\begin{array}{c}\text { 300W Xe lamp, } \\
\quad \lambda>300 \mathrm{~nm}\end{array}$ & 105 & 51.3 & 16 \\
\hline $\begin{array}{l}\text { Co1- } \\
\text { phosphide } \\
\text { /PCN }\end{array}$ & 20 & None & $\begin{array}{l}\text { 300W Xe lamp, } \\
\quad \lambda>420 \mathrm{~nm}\end{array}$ & 126.8 & 64.5 & 17 \\
\hline $\begin{array}{l}\text { Cring- } \mathrm{C}_{3} \\
\mathrm{~N}_{4}\end{array}$ & 30 & $3.0 \mathrm{wt} \% \mathrm{Pt}$ & $\begin{array}{l}\text { 300W Xe lamp, } \\
\lambda>420 \mathrm{~nm}\end{array}$ & 371 & 184 & 18 \\
\hline $\begin{array}{l}\mathrm{g}-\mathrm{C}_{3} \mathrm{~N}_{4} \\
\mathrm{NWBs}\end{array}$ & 50 & $1.0 \mathrm{wt} \% \mathrm{Pt}$ & $\begin{array}{c}300 \mathrm{~W} \text { Xe lamp } \\
\lambda \geq 300 \mathrm{~nm}\end{array}$ & 72 & 35.6 & 19 \\
\hline $\begin{array}{l}\text { PCNT-3- } \\
5\end{array}$ & 20 & $3.0 \mathrm{wt} \% \mathrm{Pt}$ & $\begin{array}{c}300 \mathrm{~W} \text { Xe lamp, } \\
\lambda \geq 420 \mathrm{~nm}\end{array}$ & 627.1 & 305.4 & 20 \\
\hline
\end{tabular}


Table S4. Summary of $\mathrm{g}-\mathrm{C}_{3} \mathrm{~N}_{4}$-based nanostructures photocatalysts reported for hydrogen evolution rate.

\begin{tabular}{|c|c|c|c|c|c|}
\hline $\begin{array}{l}\text { Photocata } \\
\text { lysts }\end{array}$ & $\begin{array}{l}\text { Catalysts } \\
\text { mass } \\
(\mathrm{mg})\end{array}$ & Reactant solution & Light Source & $\begin{array}{c}\text { Hydrogen } \\
\text { evolution rate } \\
\left(\mu \mathrm{mol} \mathrm{g}{ }^{-1} \mathrm{~h}^{-1}\right)\end{array}$ & Ref. \\
\hline $\mathrm{TCN}$ & 25 & $\begin{array}{c}25 \mathrm{~mL} \text { solution of TEOA } \\
(10 \mathrm{vol} \%) ; 3.0 \mathrm{wt} \% \mathrm{Pt}\end{array}$ & $\begin{array}{c}300 \text { W Xe lamp, } \\
\lambda>420 \mathrm{~nm}\end{array}$ & 2098 & $\begin{array}{l}\text { This } \\
\text { work }\end{array}$ \\
\hline $\begin{array}{l}\text { P-doped } \\
\text { g- } \mathrm{C}_{3} \mathrm{~N}_{4}\end{array}$ & 100 & $\begin{array}{c}100 \mathrm{~mL} \text { solution of TEOA } \\
(10 \mathrm{vol} \%) ; 3 \mathrm{wt} . \% \mathrm{Pt}\end{array}$ & $\begin{array}{c}\text { 300W Xe lamp } \\
\lambda>420 \mathrm{~nm}\end{array}$ & 506 & 21 \\
\hline P-TCN & 100 & $\begin{array}{c}100 \mathrm{~mL} \text { solution of } \\
\text { methanol } \\
(20 \mathrm{vol} \%) ; 1.0 \mathrm{wt} \% \mathrm{Pt}\end{array}$ & $\begin{array}{c}\text { 300W Xe lamp } \\
\lambda>420 \mathrm{~nm}\end{array}$ & 670 & 22 \\
\hline $\begin{array}{l}\mathrm{Al}-\mathrm{aa}(0.3 \\
2 \%)-\mathrm{PCN}\end{array}$ & 50 & $\begin{array}{l}100 \mathrm{~mL} \text { solution of TEOA } \\
(10 \mathrm{vol} \%) ; 3.0 \mathrm{wt} \% \mathrm{Pt}\end{array}$ & $\begin{array}{c}\text { 300W Xe lamp, } \\
\lambda>420 \mathrm{~nm}\end{array}$ & 1200 & 23 \\
\hline PCN-S & 20 & $\begin{array}{c}100 \mathrm{~mL} \text { solution of TEOA } \\
(10 \mathrm{vol} \%) ; 1.0 \mathrm{wt} \% \mathrm{Pt}\end{array}$ & $\begin{array}{c}\text { 300W Xe lamp, } \\
\lambda>400 \mathrm{~nm}\end{array}$ & 1596 & 24 \\
\hline $\mathrm{CNP}_{0.6}$ & 30 & $\begin{array}{c}100 \mathrm{~mL} \text { solution of TEOA } \\
(10 \mathrm{vol} \%) ; 3.0 \mathrm{wt} \% \mathrm{Pt}\end{array}$ & $\begin{array}{c}\text { 300W Xe lamp, } \\
\lambda>420 \mathrm{~nm}\end{array}$ & 7948.2 & 25 \\
\hline $\mathrm{OH}-\mathrm{CN} 3$ & 50 & $\begin{array}{c}100 \mathrm{~mL} \text { solution of lactic } \\
\operatorname{acid}(10 \mathrm{vol} \%) ; 1.0 \mathrm{wt} \% \mathrm{Pt}\end{array}$ & $\begin{array}{l}\text { 300W Xe lamp, } \\
\lambda>420 \mathrm{~nm}\end{array}$ & 310 & 26 \\
\hline PCNT-3 & 50 & $\begin{array}{l}100 \mathrm{~mL} \text { solution of TEOA } \\
(10 \mathrm{vol} \%) ; 3.0 \mathrm{wt} \% \mathrm{Pt}\end{array}$ & $\begin{array}{c}\text { 300W Xe lamp, } \\
\lambda>420 \mathrm{~nm}\end{array}$ & 2020 & 27 \\
\hline FAT-1.0 & 50 & $\begin{array}{c}50 \mathrm{~mL} \text { solution of TEOA } \\
(10 \mathrm{vol} \%) ; 3.0 \mathrm{wt} \% \mathrm{Pt}\end{array}$ & $\begin{array}{c}\text { 300W Xe lamp, } \\
420 \mathrm{~nm}<\lambda< \\
710 \mathrm{~nm}\end{array}$ & 772 & 28 \\
\hline $\begin{array}{l}\text { Few-layer } \\
\mathrm{C}_{3} \mathrm{~N}_{4}\end{array}$ & 20 & $\begin{array}{l}100 \mathrm{~mL} \text { solution of TEOA } \\
(20 \mathrm{vol} \%) ; 1.0 \mathrm{wt} \% \mathrm{Pt}\end{array}$ & $\begin{array}{l}\text { 300W Xe lamp, } \\
\lambda>420 \mathrm{~nm}\end{array}$ & 7990 & 29 \\
\hline $\mathrm{CN}-\mathrm{I}_{1.0}$ & 50 & $\begin{array}{c}100 \mathrm{~mL} \text { solution of TEOA } \\
(10 \mathrm{vol} \%) ; 3.0 \mathrm{wt} \% \mathrm{Pt}\end{array}$ & $\begin{array}{c}\text { 300W Xe lamp, } \\
\lambda>420 \mathrm{~nm}\end{array}$ & 760 & 30 \\
\hline $\begin{array}{c}\mathrm{g}-\mathrm{C}_{3} \mathrm{~N}_{4} \\
\text { nanosheet } \\
\mathrm{S}\end{array}$ & 50 & $\begin{array}{c}\text { 100mL solution of TEOA } \\
(10 \mathrm{vol} \%) ; 3.0 \mathrm{wt} \% \mathrm{Pt}\end{array}$ & $\begin{array}{l}\text { 300W Xe lamp, } \\
\lambda>420 \mathrm{~nm}\end{array}$ & 1860 & 31 \\
\hline $\mathrm{HC}-\mathrm{CN}$ & 100 & $\begin{array}{c}300 \mathrm{~mL} \text { solution of TEOA } \\
(10 \mathrm{vol} \%) ; 3.0 \mathrm{wt} \% \mathrm{Pt}\end{array}$ & $\begin{array}{c}\text { 300W Xe lamp, } \\
\lambda>400 \mathrm{~nm}\end{array}$ & 808.5 & 32 \\
\hline CHNS & 20 & $\begin{array}{c}56 \mathrm{~mL} \text { solution of TEOA } \\
(11 \mathrm{vol} \%) ; 3.0 \mathrm{wt} \% \mathrm{Pt}\end{array}$ & $\begin{array}{c}\text { 300W Xe lamp, } \\
\lambda>400 \mathrm{~nm}\end{array}$ & 2860 & 33 \\
\hline $\begin{array}{c}\mathrm{CN} \\
\text { aerogels }\end{array}$ & 50 & $\begin{array}{c}100 \mathrm{~mL} \text { solution of TEOA } \\
(10 \mathrm{vol} \%) ; 3.0 \mathrm{wt} \% \mathrm{Pt}\end{array}$ & $\begin{array}{l}\text { 300W Xe lamp, } \\
\text { Appropriate } \lambda\end{array}$ & 600 & 34 \\
\hline CNF-0.5 & 100 & $\begin{array}{c}100 \mathrm{~mL} \text { solution of TEOA } \\
(10 \mathrm{vol} \%) ; 3.0 \mathrm{wt} \% \mathrm{Pt}\end{array}$ & $\begin{array}{c}500 \mathrm{~W} \mathrm{HBO} \\
\text { lamp }\end{array}$ & 127.5 & 35 \\
\hline
\end{tabular}


Table S5. The calculated AQE at different wavelengths

\begin{tabular}{|c|c|c|c|c|c|c|c|c|c|}
\hline \multirow{2}{*}{$\begin{array}{c}\lambda \\
(\mathbf{n m})\end{array}$} & \multirow{2}{*}{$\begin{array}{c}S \\
\left(\mathbf{c m}^{2}\right)\end{array}$} & \multirow{2}{*}{$\begin{array}{c}I \\
\left(\mathbf{m W ~ \mathbf { c m } ^ { - 2 }}\right)\end{array}$} & \multirow{2}{*}{$t(s)$} & \multirow{2}{*}{$h$} & \multirow{2}{*}{$c$} & \multicolumn{2}{|c|}{$\begin{array}{c}\text { n }\left(\mathrm{H}_{2}-\mu \mathrm{mol}\right. \\
\left.\mathbf{h}^{-1}\right)\end{array}$} & \multicolumn{2}{|c|}{ AQY \% } \\
\hline & & & & & & $\mathbf{C}_{3} \mathbf{N}_{4}$ & TCN & $\mathbf{C}_{3} \mathbf{N}_{4}$ & TCN \\
\hline 395 & 4.52 & 4.96 & 3600 & $6.63 \times 10^{-34}$ & $3 \times 10^{8}$ & 1.49 & 7.32 & $1.12 \%$ & $5.49 \%$ \\
\hline 420 & 5.31 & 4.08 & 3600 & $6.63 \times 10^{-34}$ & $3 \times 10^{8}$ & 0.42 & 4.47 & $0.30 \%$ & $3.27 \%$ \\
\hline 500 & 4.52 & 1.62 & 3600 & $6.63 \times 10^{-34}$ & $3 \times 10^{8}$ & 0.10 & 0.23 & $0.19 \%$ & $0.41 \%$ \\
\hline 595 & 9.08 & 2.38 & 3600 & $6.63 \times 10^{-34}$ & $3 \times 10^{8}$ & 0 & 0.02 & 0 & $0.01 \%$ \\
\hline
\end{tabular}




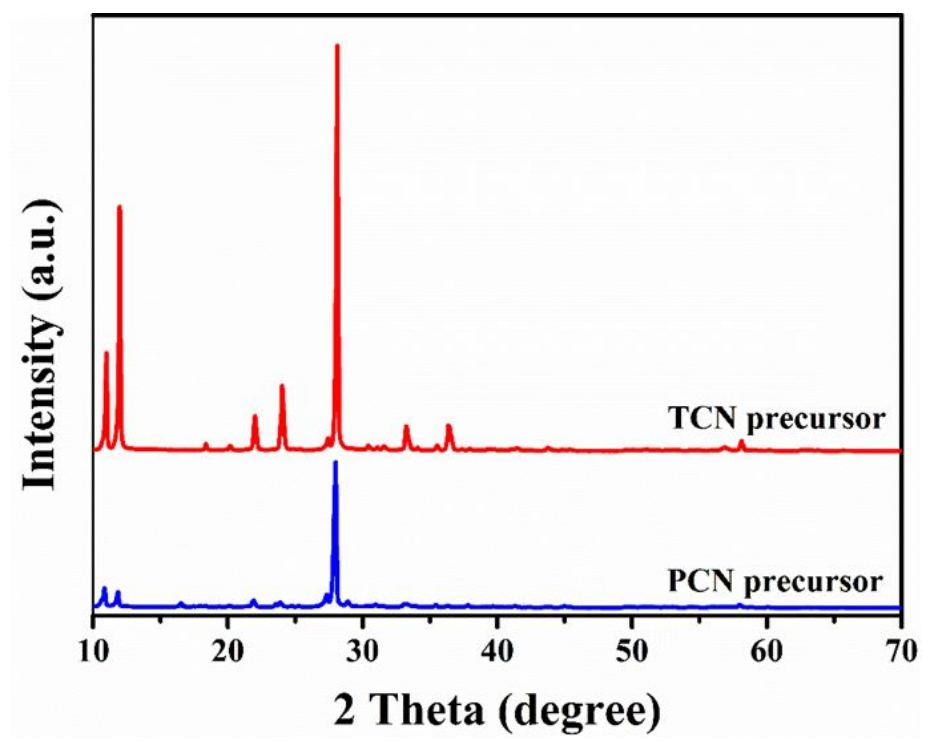

Figure S1. XRD of TCN and PCN precursors.

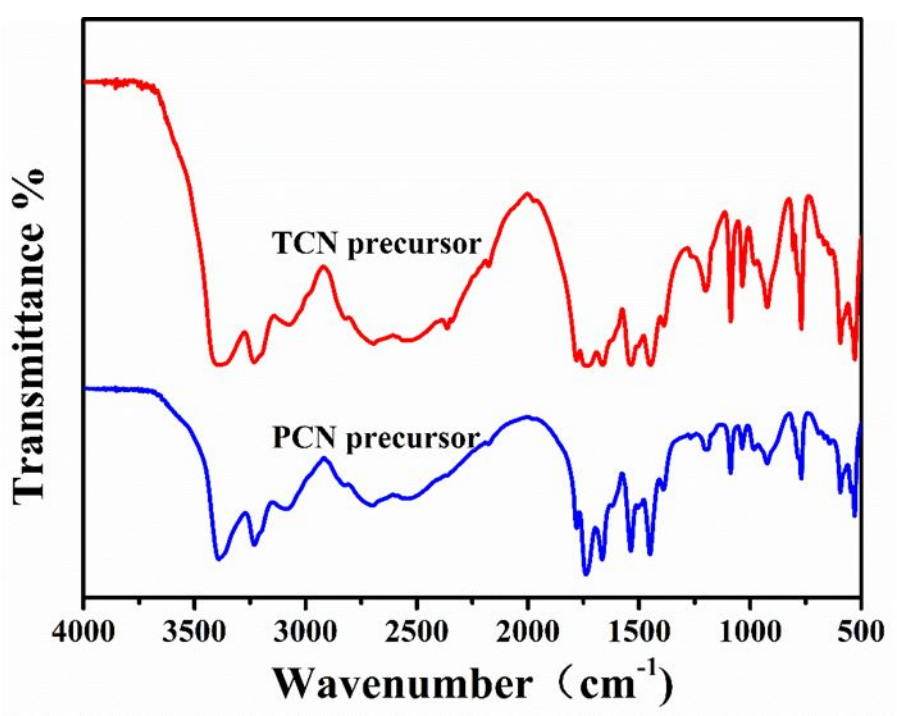

Figure S2. FT-IR of TCN and PCN precursors. 

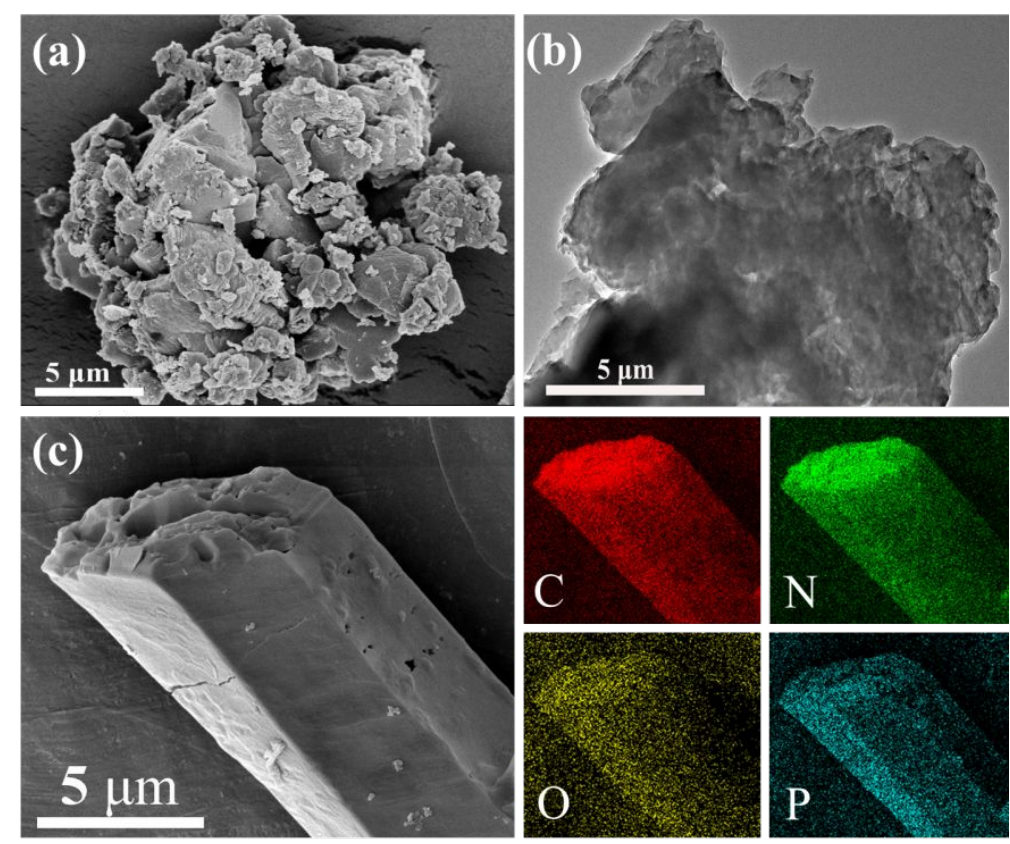

Figure S3. SEM images of (a) g- $\mathrm{C}_{3} \mathrm{~N}_{4}$, TEM imanges of (b) $\mathrm{g}-\mathrm{C}_{3} \mathrm{~N}_{4}$, and SEM elemental mapping of (c) PCN.

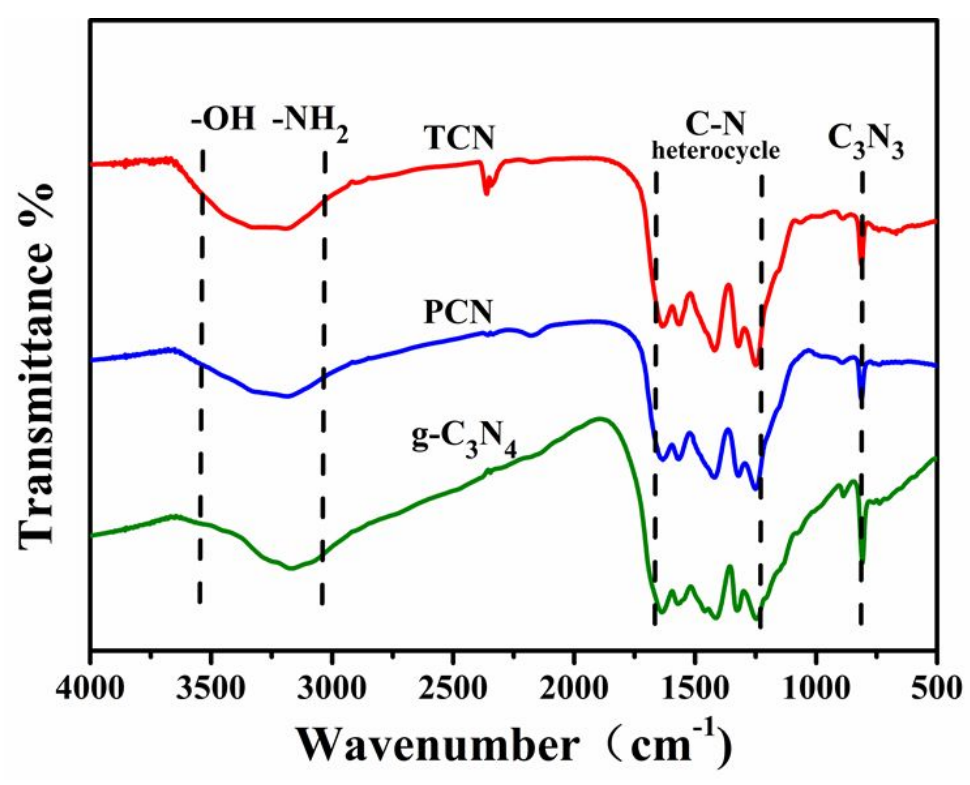

Figure S4. FT-IR of the prepared samples. 


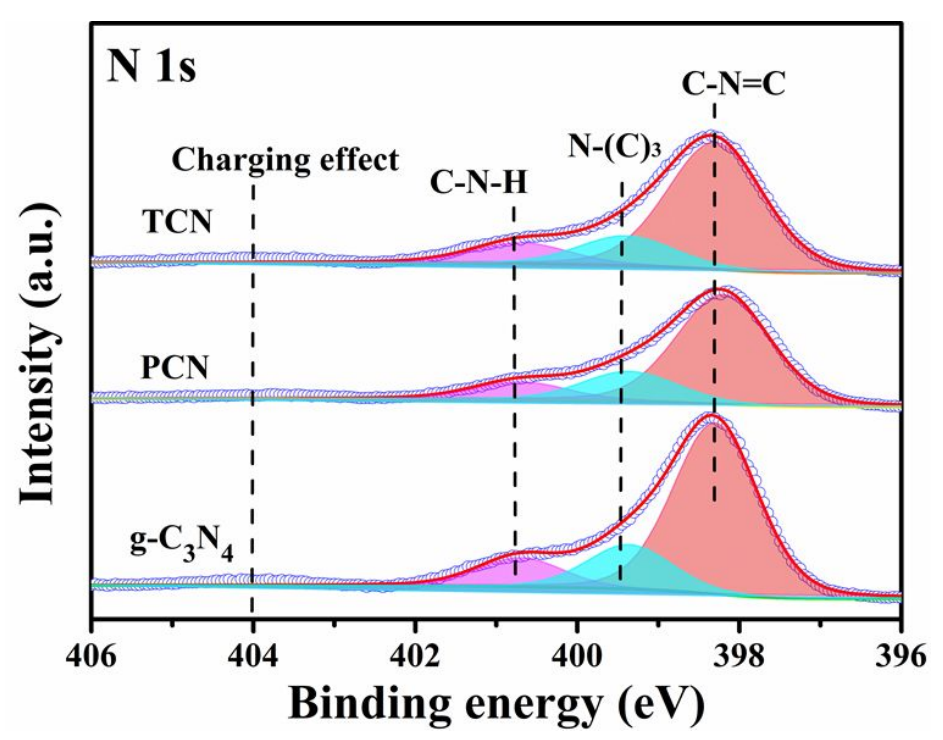

Figure S5. XPS N 1s spectra of the prepared samples.

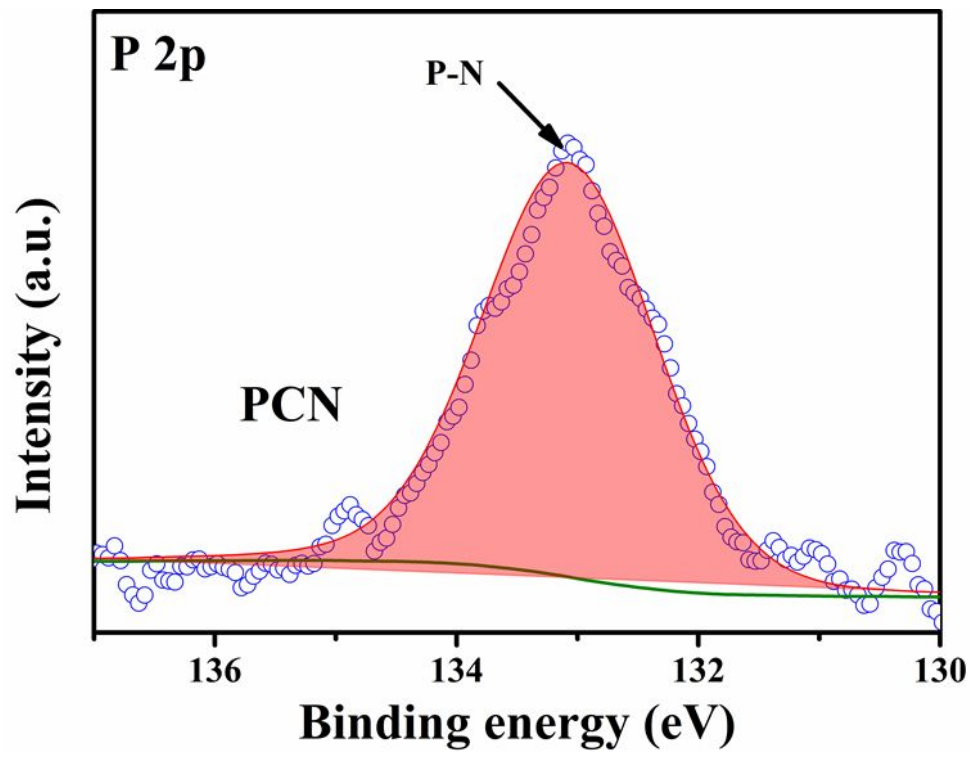

Figure S6. XPS P 2p spectra of the PCN. 


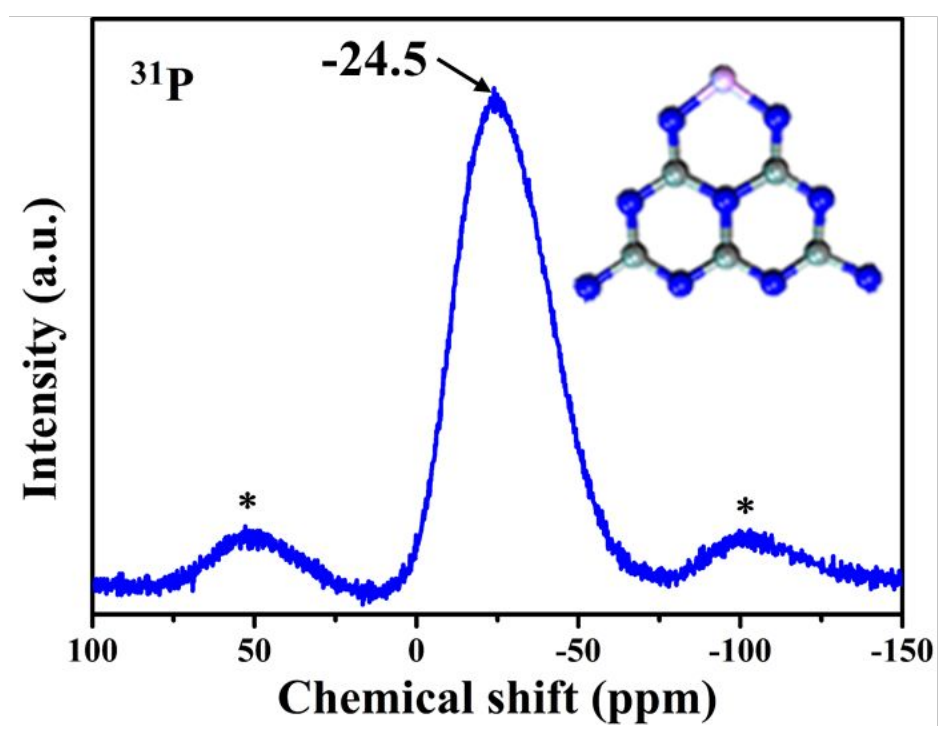

Figure S7. Solid-state ${ }^{31} \mathrm{P}$ NMR spectra of the PCN.

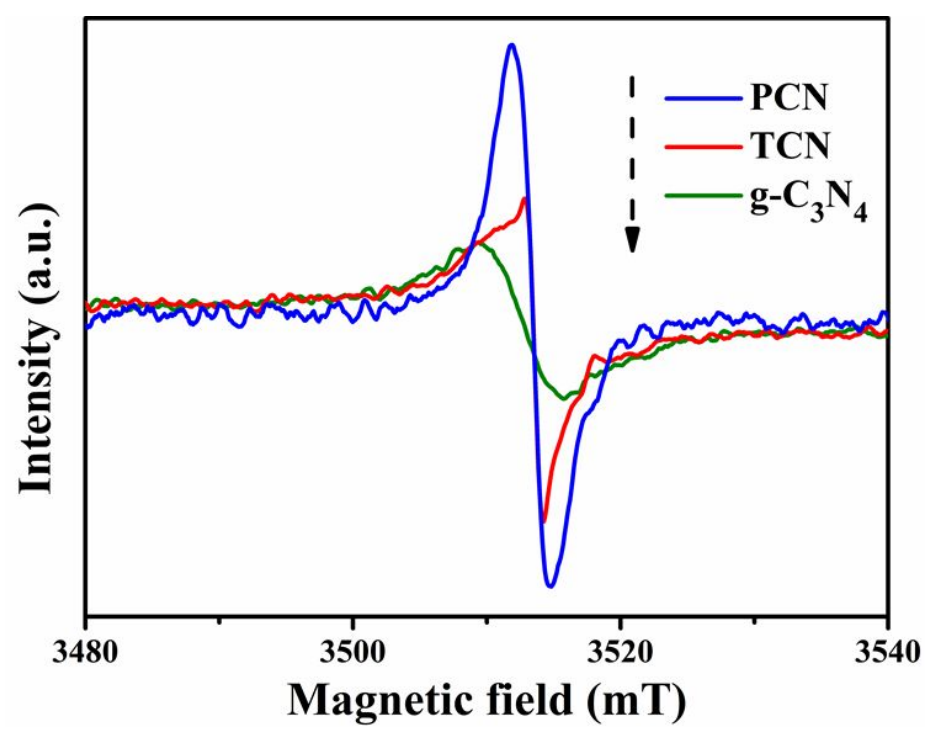

Figure S8. EPR of the prepared samples. 

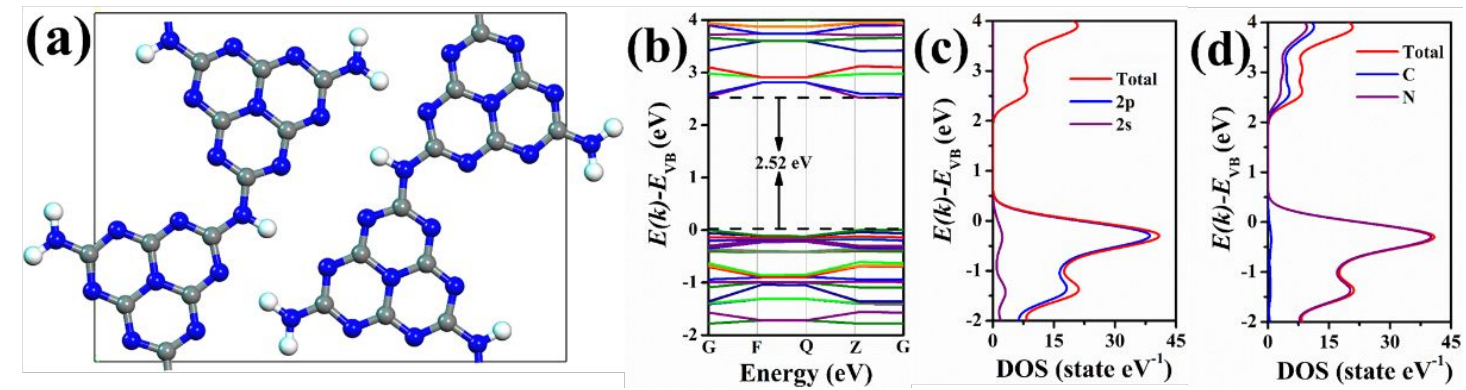

Figure S9. DFT calculation results of plain g- $\mathrm{C}_{3} \mathrm{~N}_{4}$. (a) Unit cell, (b) band structure, (c) DOS decomposed with respect to different electron orbitals, and (d) with respect of different elements.

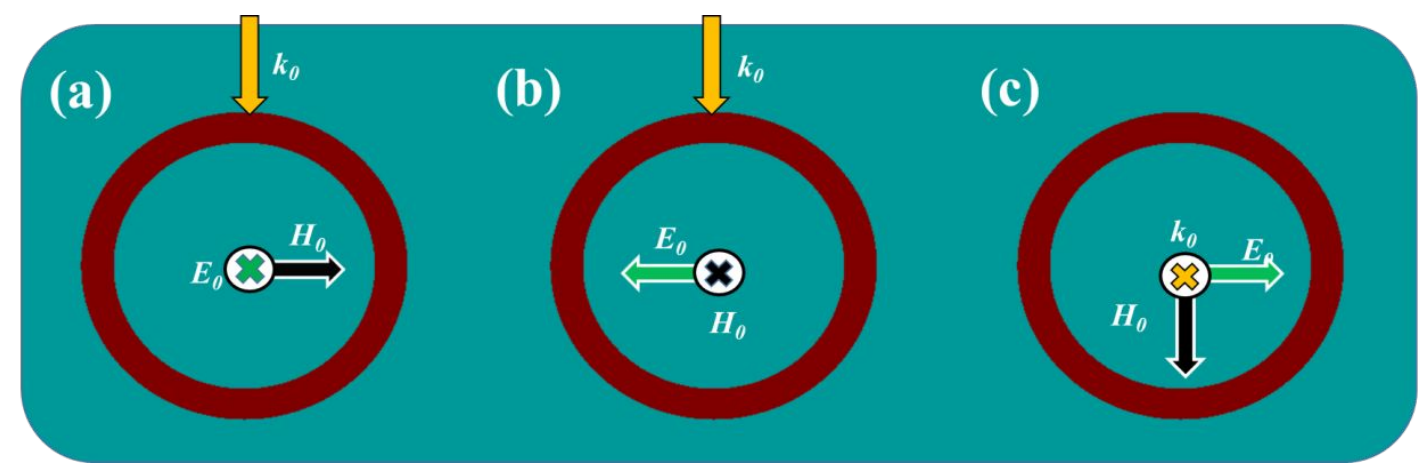

Figure S10. Schematic diagram of the FEM model of TCN tube (not to scale) and the field orientations. The areas in red and blue colures represent $g-\mathrm{C}_{3} \mathrm{~N}_{4}$ material and water, respectively. The directions of the incoming radiation $\boldsymbol{k}_{\boldsymbol{\theta}}$, the electrical field $\boldsymbol{E}_{\boldsymbol{\theta}}$ and the magnetic field $\boldsymbol{H}_{\boldsymbol{\theta}}$ are shown by the yellow, green and black arrows, respectively. (a) TM mode, (b) TE mode, and (c) TM+TE mode. 


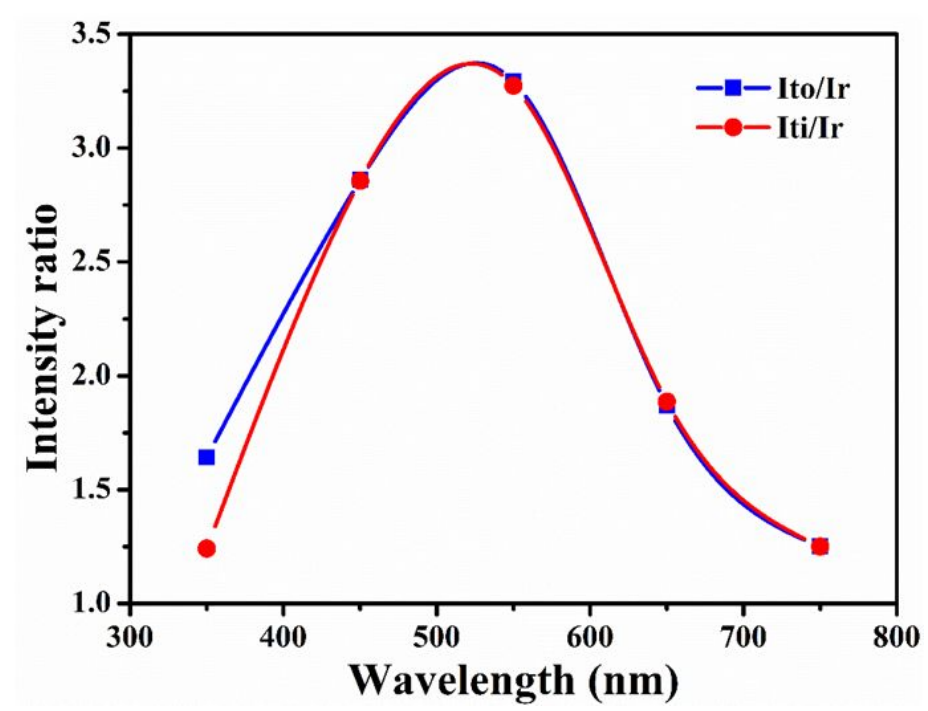

Figure S11. The ratio of near filed intensity averaged over the periphery of the rod and tube. $I_{t o}, I_{t i}$, and $I_{r}$ represent the average intensity over the outer wall, inner wall of the TCN, and that along the wall of the PCN, respectively.

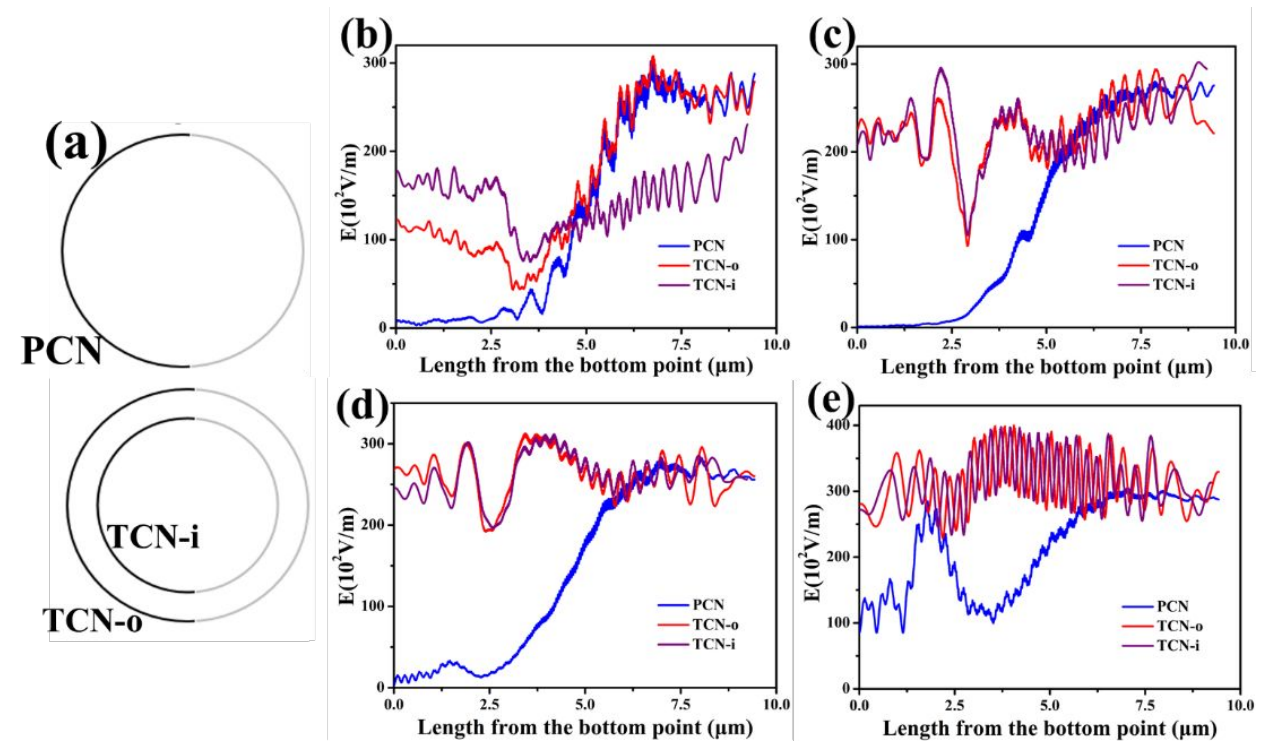

Figure S12 The FEM results of the electrical field distribution along the periphery lines for the PCN and the TCN, in TM mode. (a) A schematic illustration of the lines for the PCN and TCN along which the $\boldsymbol{E}$ field distributions are plotted, (b)-(e) The FEM results of the electrical field distribution along the lines in (a) for the PCN and the TCN, in TM mode, at 350, 450, 550, and $650 \mathrm{~nm}$ irradiation wavelengths, respectively. 

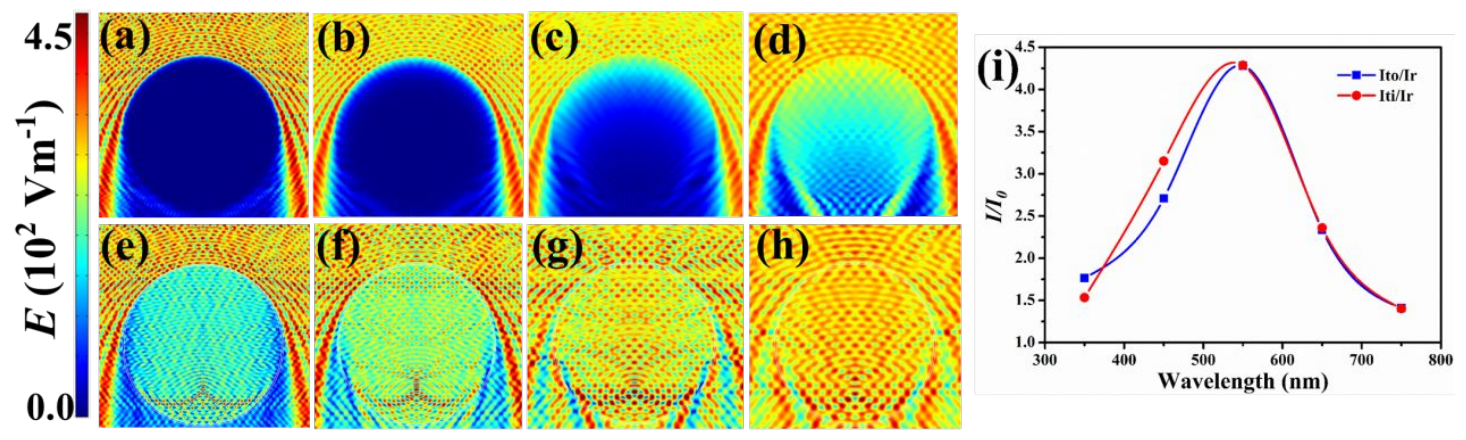

Figure S13. The FEM results of the electrical field distribution, in TE mode, over the cross section of the PCN of $6 \mu \mathrm{m}$ in diameter at (a) $350 \mathrm{~nm}$, (b) $450 \mathrm{~nm}$, (c) $550 \mathrm{~nm}$, (d) $650 \mathrm{~nm}$ irradiation wavelengths, and the field distribution over the cross section of a TCN of the same diameter, with a wall thickness $60 \mathrm{~nm}$, at (e) $350 \mathrm{~nm}$, (f) $450 \mathrm{~nm}$, (g) $550 \mathrm{~nm}$, (h) $650 \mathrm{~nm}$ irradiation wavelengths. (i) The ratio of near filed intensity averaged over the periphery of the rod and tube. $I_{t o}, I_{t i}$, and $I_{r}$ represent the average intensity over the outer wall, inner wall of the tube, and that along the wall of the rod, respectively.
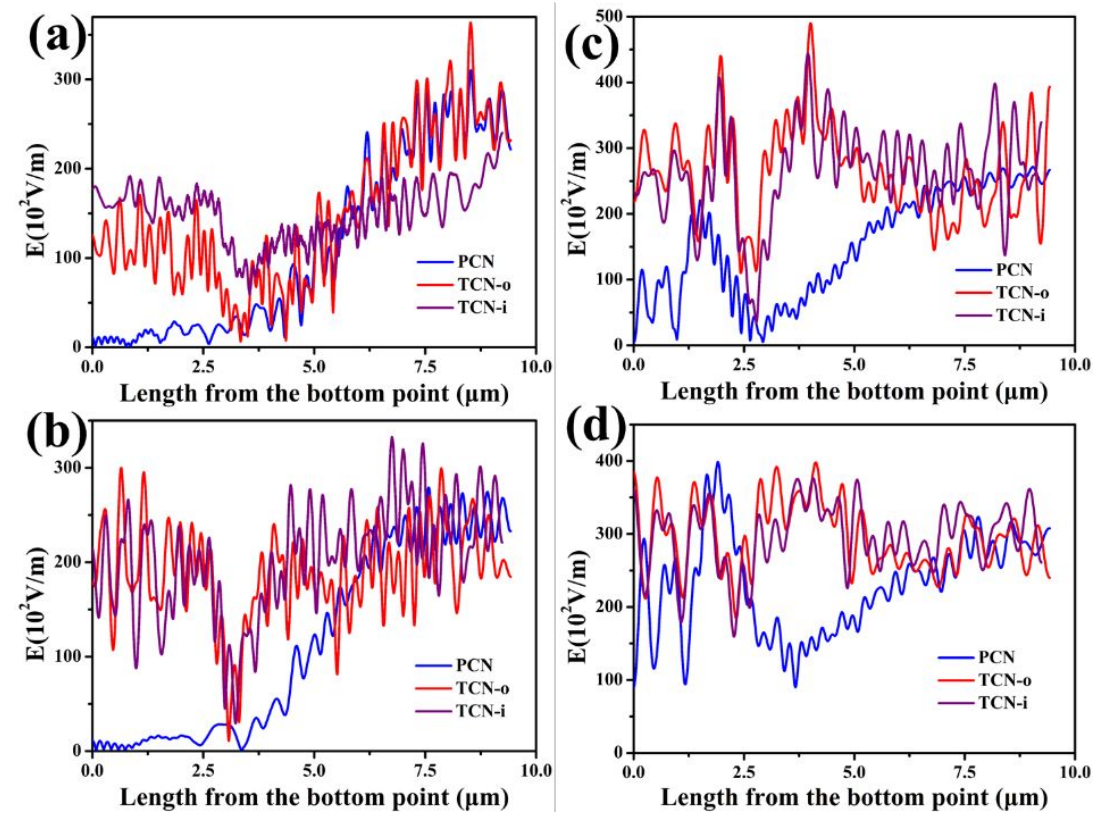

Figure S14. The FEM results of the electrical field distribution along the periphery lines for the PCN and the TCN, in TE mode. (a)-(d) The FEM results of the electrical field distribution along the lines for the PCN and the TCN, in TE mode, at $350 \mathrm{~nm}, 450 \mathrm{~nm}, 550 \mathrm{~nm}$, and $650 \mathrm{~nm}$ irradiation wavelengths, respectively. 

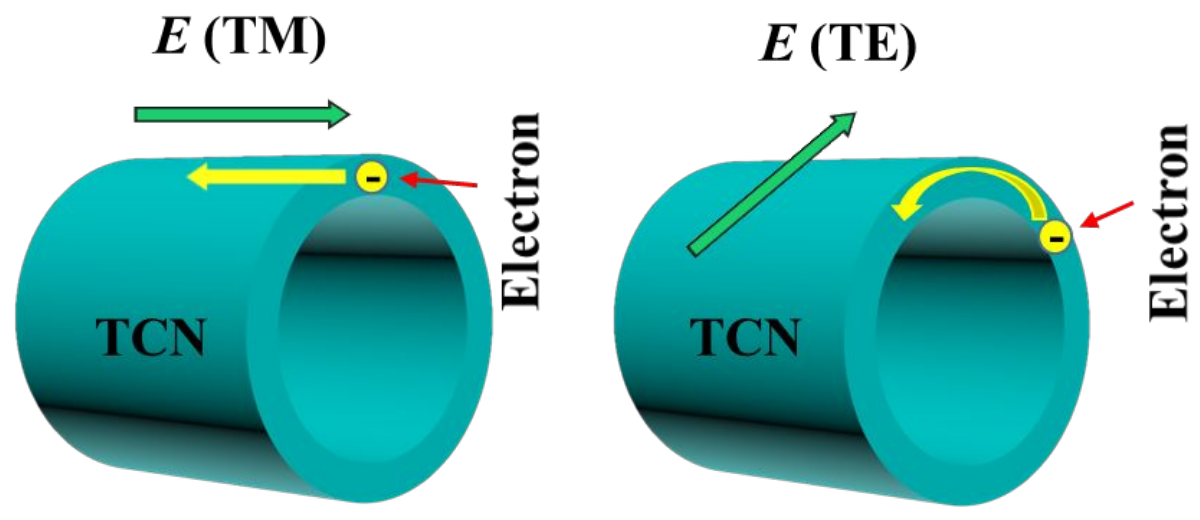

Figure S15. The schematics of the plasmonic electron movement within TCN, when illuminated by $\mathrm{TM}$ and TE field radiations, respectively.

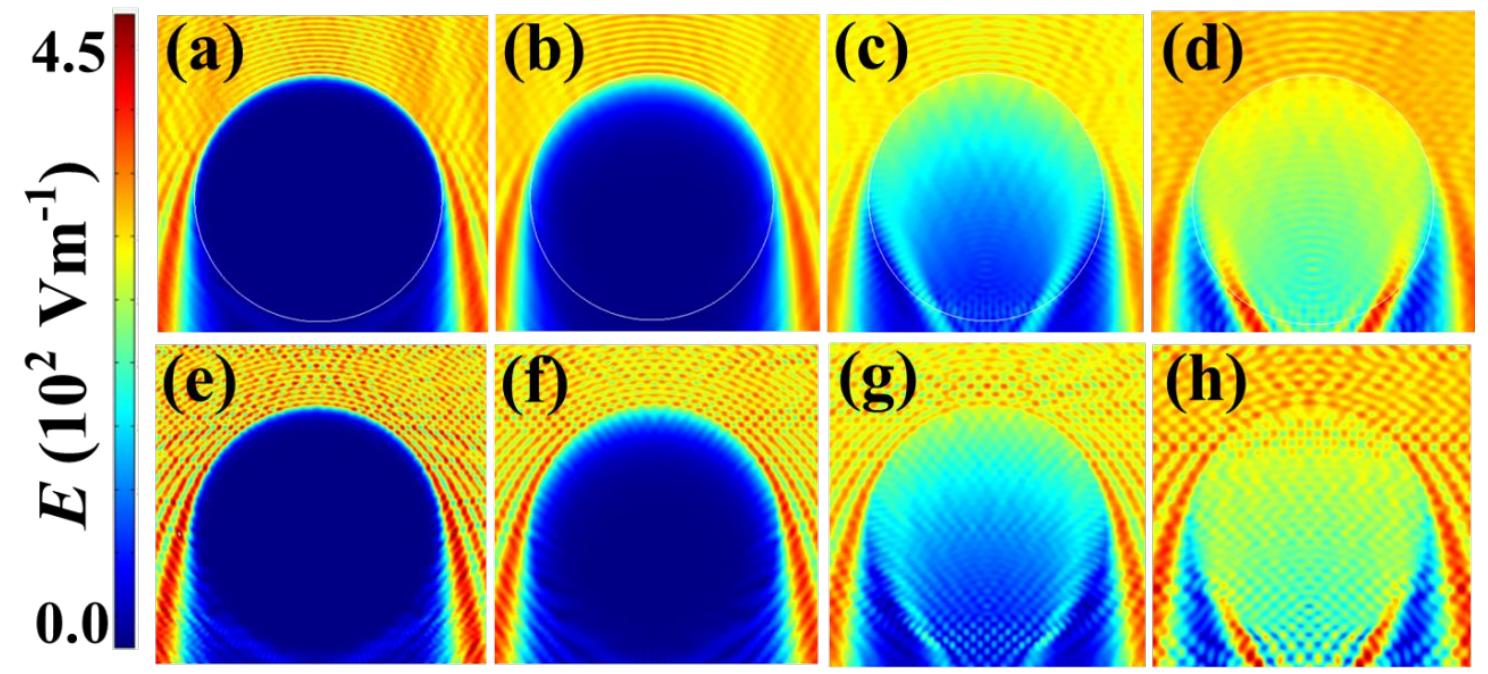

Figure S16. The FEM results of the electrical field distribution over the cross section of plain g- $\mathrm{C}_{3} \mathrm{~N}_{4}$ rod of $6 \mu \mathrm{m}$ in diameter at different wavelengths, in TM mode, (a) $350 \mathrm{~nm}$, (b) $450 \mathrm{~nm}$, (c) $550 \mathrm{~nm}$, (d) $650 \mathrm{~nm}$ irradiation wavelengths, in TE mode, (e) $350 \mathrm{~nm}$, (f) $450 \mathrm{~nm},(\mathrm{~g}) 550 \mathrm{~nm}$, (h) $650 \mathrm{~nm}$ irradiation wavelengths. 


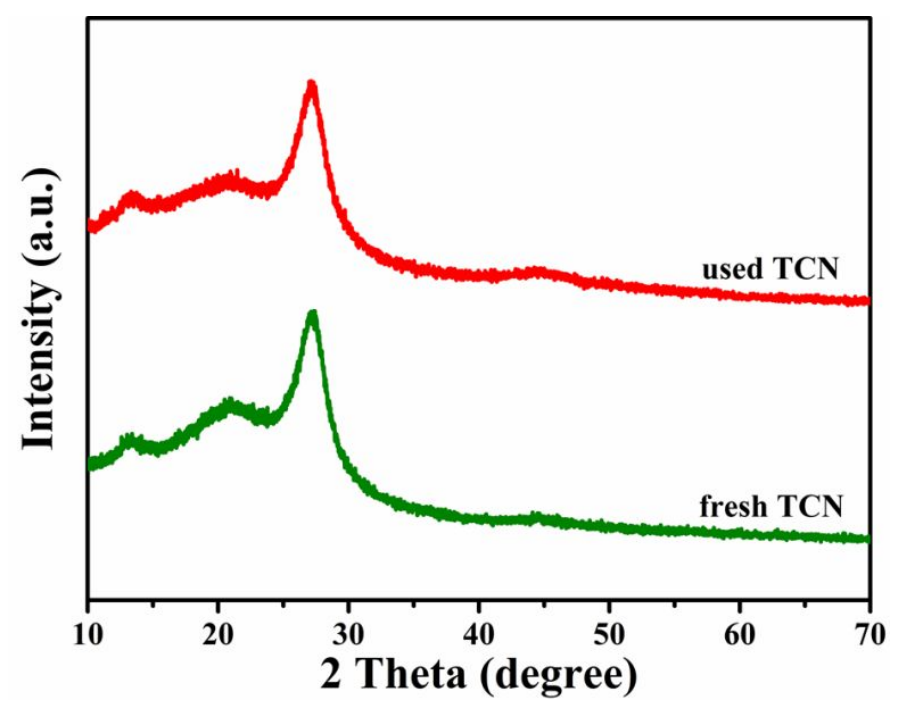

Figure S17. XRD patterns of TCN fresh and used four reaction cycles

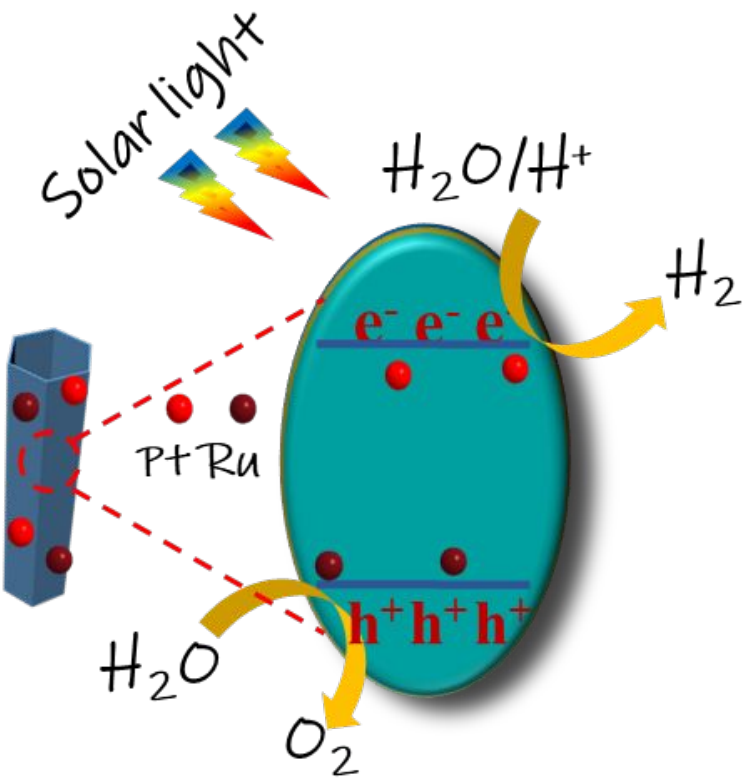

Figure S18. The reaction mechanism of TCN. 


\section{References}

(1) Clark, S. J.; Segall, M. D.; Pickard, C. J.; Hasnip, P. J.; Probert, M. I.; Refson, K.; Payne,

M. C. First principles methods using CASTEP. Z. Krist. Cryst. Mater. 2005, 220, 567-570, DOI 10.1524/zkri.220.5.567.65075.

(2) Perdew, J. P.; Burke, K.; Ernzerhof, M. Generalized gradient approximation made simple. Phys. Rev. Lett. 1996, 77, 3865-3868, DOI 10.1103/PhysRevLett.77.3865.

(3) Lotsch, B. V.; Döblinger, M.; Sehnert, J.; Seyfarth, L.; Senker, J.; Oeckler, O.; Schnick, W. Unmasking melon by a complementary approach employing electron diffraction, solid-state NMR spectroscopy, and theoretical calculations - structural characterization of a carbon nitride polymer. Chem. Eur. J. 2007, 13, 4969-4980, DOI 10.1002/chem.200601759.

(4) Wang, X.; Maeda, K.; Thomas, A.; Takanabe, K.; Xin, G.; Carlsson, J. M.; Domen, K.; Antonietti, M. A metal-free polymeric photocatalyst for hydrogen production from water under visible light. Nat. Mater. 2009, 8, 76-80, DOI 10.1038/nmat2317.

(5) Mo, Z.; Xu, H.; She, X.; Song, Y.; Yan, P.; Yi, J.; Zhu, X.; Lei, Y.; Yuan, S.; Li, H. Constructing $\mathrm{Pd} / 2 \mathrm{D}-\mathrm{C}_{3} \mathrm{~N}_{4}$ composites for efficient photocatalytic $\mathrm{H}_{2}$ evolution through nonplasmon-induced bound electrons. Appl. Surf. Sci. 2019, 467-468, 151-157, DOI 10.1016/j.apsusc.2018.10.115.

(6) Wang, S.; Zhao, H.; Zhao, X.; Zhang, J.; Ao, Z.; Dong, P.; He, F.; Wu, H.; Xu, X.; Shi, L.; Zhao, C.; Wang, S.; Sun, H. Surface engineering of hollow carbon nitride microspheres for efficient photoredox catalysis. Chem. Eng. J. 2020, 381, 122593, DOI 10.1016/j.cej.2019.122593.

(7) Pryor, R. W., Multiphysics modeling using COMSOL®: a first principles approach. Jones 
\& Bartlett Publishers: 2009.

(8) Govorov, A. O.; Richardson, H. H. Generating heat with metal nanoparticles. Nano today. 2007, 2, 30-38, DOI 10.1016/S1748-0132(07)70017-8.

(9) Niu, P.; Qiao, M.; Li, Y.; Huang, L.; Zhai, T. Distinctive defects engineering in graphitic carbon nitride for greatly extended visible light photocatalytic hydrogen evolution. Nano Energy. 2018, 44, 73-81, DOI 10.1016/j.nanoen.2017.11.059.

(10) Chen, X.; Shi, R.; Chen, Q.; Zhang, Z.; Jiang, W.; Zhu, Y.; Zhang, T. Three-dimensional porous g-C3N4 for highly efficient photocatalytic overall water splitting. Nano Energy. 2019, 59, 644-650, DOI 10.1016/j.nanoen.2019.03.010.

(11) Zhang, G.; Lan, Z. A.; Lin, L.; Lin, S.; Wang, X. Overall water splitting by Pt/g- $\mathrm{C}_{3} \mathrm{~N}_{4}$ photocatalysts without using sacrificial agents. Chem. Sci. 2016, 7, 3062-3066, DOI $10.1039 / \mathrm{c} 5 \mathrm{sc} 04572 \mathrm{j}$

(12) Zheng, D.; Cao, X. N.; Wang, X. Precise formation of a hollow carbon nitride structure with a janus surface to promote water splitting by photoredox catalysis. Angew. Chem. Int. Ed. 2016, 55, 11684-11688, DOI 10.1002/anie.201606102.

(13) She, X.; Wu, J.; Xu, H.; Zhong, J.; Wang, Y.; Song, Y.; Nie, K.; Liu, Y.; Yang, Y.; Rodrigues, M.-T. F.; Vajtai, R.; Lou, J.; Du, D.; Li, H.; Ajayan, P. M. High efficiency photocatalytic water splitting using $2 \mathrm{D} \alpha-\mathrm{Fe}_{2} \mathrm{O}_{3} / \mathrm{gC}_{3} \mathrm{~N}_{4}$ Z-Scheme catalysts. Adv. Energy Mater. 2017, 7, 1700025, DOI 10.1002/aenm.201700025.

(14) Zhu, M.; Sun, Z.; Fujitsuka, M.; Majima, T. Z-Scheme photocatalytic water splitting on a 2D heterostructure of black phosphorus/bismuth vanadate using visible light. Angew. Chem. Int. Ed. 2018, 57, 2160-2164, DOI 10.1002/anie.201711357. 
(15) Martin, D. J.; Reardon, P. J.; Moniz, S. J.; Tang, J. Visible light-driven pure water splitting by a nature-inspired organic semiconductor-based system. J. Am. Chem. Soc. 2014, 136, 12568-12571, DOI 10.1021/ja506386e.

(16) Liu, J.; Liu, Y.; Liu, N.; Han, Y.; Zhang, X.; Huang, H.; Lifshitz, Y.; Lee, S.-T.; Zhong, J.; Kang, Z. Metal-free efficient photocatalyst for stable visible water splitting via a two-electron pathway. Science. 2015, 347, 970-974, DOI 10.1126/science.aaa3145.

(17) Liu, W.; Cao, L.; Cheng, W.; Cao, Y.; Liu, X.; Zhang, W.; Mou, X.; Jin, L.; Zheng, X.; Che, W.; Liu, Q.; Yao, T.; Wei, S. Single-site active cobalt-based photocatalyst with a long carrier lifetime for spontaneous overall water splitting. Angew. Chem. Int. Ed. 2017, 56, 9312-9317, DOI 10.1002/anie.201704358.

(18) Che, W.; Cheng, W.; Yao, T.; Tang, F.; Liu, W.; Su, H.; Huang, Y.; Liu, Q.; Liu, J.; Hu, F.; Pan, Z.; Sun, Z.; Wei, S. Fast photoelectron transfer in (Cring)- $\mathrm{C}_{3} \mathrm{~N}_{4}$ plane heterostructural nanosheets for overall water splitting. J. Am. Chem. Soc. 2017, 139, 3021-3026, DOI 10.1021/jacs.6b11878.

(19) Zhang, K.; Wang, L.; Sheng, X.; Ma, M.; Jung, M. S.; Kim, W.; Lee, H.; Park, J. H. Tunable Bandgap Energy and Promotion of $\mathrm{H}_{2} \mathrm{O}_{2}$ Oxidation for Overall Water Splitting from Carbon Nitride Nanowire Bundles. Adv. Energy Mater. 2016, 6, 1502352, DOI 10.1002/aenm.201502352.

(20) Ai, Z.; Shao, Y.; Chang, B.; Zhang, L.; Shen, J.; Wu, Y.; Huang, B.; Hao, X. Rational modulation of p-n homojunction in P-doped g- $\mathrm{C}_{3} \mathrm{~N}_{4}$ decorated with $\mathrm{Ti}_{3} \mathrm{C}_{2}$ for photocatalytic overall water splitting. Appl. Catal., B. 2019, 259, 118077, DOI 10.1016/j.apcatb.2019.118077. 
(21) Zhou, Y.; Zhang, L.; Liu, J.; Fan, X.; Wang, B.; Wang, M.; Ren, W.; Wang, J.; Li, M.;

Shi, J. Brand new P-doped $\mathrm{g}-\mathrm{C}_{3} \mathrm{~N}_{4}$ : enhanced photocatalytic activity for $\mathrm{H}_{2}$ evolution and Rhodamine B degradation under visible light. J. Mater. Chem. A. 2015, 3, 3862-3867, DOI $10.1039 / \mathrm{c} 4 \mathrm{ta} 05292 \mathrm{~g}$.

(22) Guo, S.; Deng, Z.; Li, M.; Jiang, B.; Tian, C.; Pan, Q.; Fu, H. Phosphorus-doped carbon nitride tubes with a layered micro-nanostructure for enhanced visible-light photocatalytic hydrogen evolution. Angew. Chem. Int. Ed. 2016, 55, 1862-1866, DOI 10.1002/anie.201508505.

(23) Choi, C. H.; Lin, L.; Gim, S.; Lee, S.; Kim, H.; Wang, X.; Choi, W. Polymeric carbon nitride with localized aluminum coordination sites as a durable and efficient photocatalyst for visible light Utilization. ACS Catal. 2018, 8, 4241-4256, DOI 10.1021/acscatal.7b03512.

(24) Ran, J.; Ma, T. Y.; Gao, G.; Du, X.-W.; Qiao, S. Z. Porous P-doped graphitic carbon nitride nanosheets for synergistically enhanced visible-light photocatalytic $\mathrm{H}_{2}$ production. Energy Environ. Sci. 2015, 8, 3708-3717, DOI 10.1039/c5ee02650d.

(25) Wan, S.; Ou, M.; Wang, Y.; Zeng, Y.; Xiong, Y.; Song, F.; Ding, J.; Cai, W.; Zhang, S.; Zhong, Q. Protonic acid-assisted universal synthesis of defect abundant multifunction carbon nitride semiconductor for highly-efficient visible light photocatalytic applications. Appl. Catal., B. 2019, 258, 118011, DOI 10.1016/j.apcatb.2019.118011.

(26) Yu, S.; Li, J.; Zhang, Y.; Li, M.; Dong, F.; Zhang, T.; Huang, H. Local spatial charge separation and proton activation induced by surface hydroxylation promoting photocatalytic hydrogen evolution of polymeric carbon nitride. Nano Energy. 2018, 50, 383-392, DOI 10.1016/j.nanoen.2018.05.053. 
(27) Wu, M.; Zhang, J.; He, B.-b.; Wang, H.-w.; Wang, R.; Gong, Y.-s. In-situ construction of coral-like porous P-doped g- $\mathrm{C}_{3} \mathrm{~N}_{4}$ tubes with hybrid 1D/2D architecture and high efficient photocatalytic hydrogen evolution. Appl. Catal., B. 2019, 241, 159-166, DOI 10.1016/j.apcatb.2018.09.037.

(28) Wang, Y.; Silveri, F.; Bayazit, M. K.; Ruan, Q.; Li, Y.; Xie, J.; Catlow, C. R. A.; Tang, J. Bandgap engineering of organic semiconductors for highly efficient photocatalytic water splitting. Adv. Energy Mater. 2018, 8, 1801084, DOI 10.1002/aenm.201801084.

(29) Xiao, Y.; Tian, G.; Li, W.; Xie, Y.; Jiang, B.; Tian, C.; Zhao, D.; Fu, H. Molecule self-assembly synthesis of porous few-layer carbon nitride for highly efficient photoredox catalysis. J. Am. Chem. Soc. 2019, 141, 2508-2515, DOI 10.1021/jacs.8b12428.

(30) Zhang, G.; Zhang, M.; Ye, X.; Qiu, X.; Lin, S.; Wang, X. Iodine modified carbon nitride semiconductors as visible light photocatalysts for hydrogen evolution. Adv. Mater. 2014, 26, 805-809, DOI 10.1002/adma.201303611.

(31) Yang, S.; Gong, Y.; Zhang, J.; Zhan, L.; Ma, L.; Fang, Z.; Vajtai, R.; Wang, X.; Ajayan, P. M. Exfoliated graphitic carbon nitride nanosheets as efficient catalysts for hydrogen evolution under visible light. Adv. Mater. 2013, 25, 2452-2456, DOI 10.1002/adma.201204453.

(32) Xing, W.; Tu, W.; Han, Z.; Hu, Y.; Meng, Q.; Chen, G. Template-Induced High-Crystalline g- $\mathrm{C}_{3} \mathrm{~N}_{4}$ Nanosheets for Enhanced Photocatalytic $\mathrm{H}_{2}$ Evolution. ACS Energy Letters. 2018, 3, 514-519, DOI 10.1021/acsenergylett.7b01328.

(33) Li, Y.; Jin, R.; Xing, Y.; Li, J.; Song, S.; Liu, X.; Li, M.; Jin, R. Macroscopic foam-like holey ultrathin $\mathrm{g}_{-} \mathrm{C}_{3} \mathrm{~N}_{4}$ nanosheets for drastic improvement of visible-light photocatalytic 
activity. Adv. Energy Mater. 2016, 6, 1601273, DOI 10.1002/aenm.201601273.

(34) Ou, H.; Yang, P.; Lin, L.; Anpo, M.; Wang, X. Carbon nitride aerogels for the photoredox conversion of water. Angew. Chem. Int. Ed. 2017, 56, 10905-10910, DOI 10.1002/anie.201705926.

(35) Wang, Y.; Di, Y.; Antonietti, M.; Li, H.; Chen, X.; Wang, X. Excellent visible-light photocatalysis of fluorinated polymeric carbon nitride solids. Chem. Mater. 2010, 22, 5119-5121, DOI 10.1021/cm1019102. 